Fournal of Medical Genetics (1975). 12, 55.

\title{
Thalassaemia in northern Liberia. A survey in the Mount Nimba area
}

\author{
M. C. WILLCOX* \\ Medical Department, Lamco Yekepa, Roberts International Airport, Liberia
}

\begin{abstract}
Summary. A population survey in northern Liberia showed an average incidence of $9 \%$ of $\beta$-thalassaemia trait. There was considerable tribal variation, the highest rates being mainly found in tribes having a low incidence of $\mathrm{Hb} \mathrm{S}$. A single example of $\delta \beta$-thalassaemia trait was also found; the incidence of $\delta$-chain variants was $1.8 \%$. The effect of malaria on $\mathrm{Hb} \mathrm{A}_{2}$ levels was investigated but appeared to be negligible. The problems of $\beta$-thalassaemia and $\mathrm{Hb} \mathrm{S}$ occurring in the same population are discussed. It is considered that, although made on a local sample, the results of this survey indicate a high incidence of $\beta$-thalassaemia trait elsewhere in Liberia and that this is a suitable area for investigations of linkage at $\beta$ - and $\delta$ chain loci. No conclusion is at present possible from the data on the presence of $\alpha$-thalassaemia although $10 \%$ of neonates were found to have increased levels of $\mathrm{Hb}$ Barts.
\end{abstract}

When Olesen and his co-workers (1959) reported two cases of thalassaemia major in children from south-east Liberia it was only the second time that this condition had been described in Africa south of the Sahara. A small survey made by the authors, although invalid for accurate incidence figures because it contained a number of non-random samples, showed about $11 \%$ to have a raised level of $\mathrm{Hb} \mathrm{A}_{2}$, a remarkable proportion for a negro population.

In a later survey, Neel et al (1961) estimated the incidence of thalassaemia trait in Liberia to be about 4-6\%. Although this figure is considerably lower that the earlier one of Olesen et al (1959) it is still one of the highest reported in several investigations on West African populations (Watson-Williams, 1965; Esan, 1970; Weatherall et al, 1971); only northern Ghana (Ringelhann et al, 1968) and possibly Upper Volta (Rucknagel and Neel, 1961) appear to have comparable frequencies.

In spite of the importance of these early findings, however, no further studies appear to have been made on thalassaemia in Liberia and it is the purpose of this report to present fresh data. These

Received 16 May 1974.

* Present address: Bakteriologiska Laboratoriet, Gävle Sjukhus, S-800 07 Gävle, Sweden. come from northern Liberia where it was decided to embark on further surveys since cases of homozygous $\beta$-thalassaemia and other thalassaemia syndromes were being seen quite frequently at a hospital situated in the vicinity of Mount Nimba (Willcox, Weatherall, and Clegg, 1975).

Since the main criteria for the detection of $\beta$ thalassaemia was an elevated $\mathrm{Hb} \mathrm{A_{2 }}$ level, and as malaria is endemic in Liberia-especially in the Nimba area it was essential to consider the effect that this infection could have on the results in view of reports (Arends, 1967; Eng, Lopez, and Lopes, 1971) that malaria may cause a rise in $\mathrm{Hb} \mathrm{A}_{2}$ even into the thalassaemia range. Part of the survey was devoted to this problem.

\section{Materials and methods}

Geographical location. The Nimba Range lies in the northern tip of central Liberia and extends into Guinea. On the Liberian side it is the site of a large iron ore mine and the town of Yekepa with a population of around 10 thousand was constructed by the Lamco J.V. Operating Company to house its employees. The location in the district of a mining concession brings many persons, with their families, to seek employment. In addition, the community, with its hospital, close to 55 
connected with the Company for a variety of reasons. Thus most Liberian tribes are represented in the district; the majority however are Mano.

These tribes, although fairly homogenous culturally, have been classified on a language basis into West Atlantic, Mande-tan, Mande-fu, and Kru groups (Greenberg, 1955). The tribes are not confined within the borders of Liberia but some extend into the neighbouring republics. The approximate areas occupied by the various tribes are shown in Figure 1.

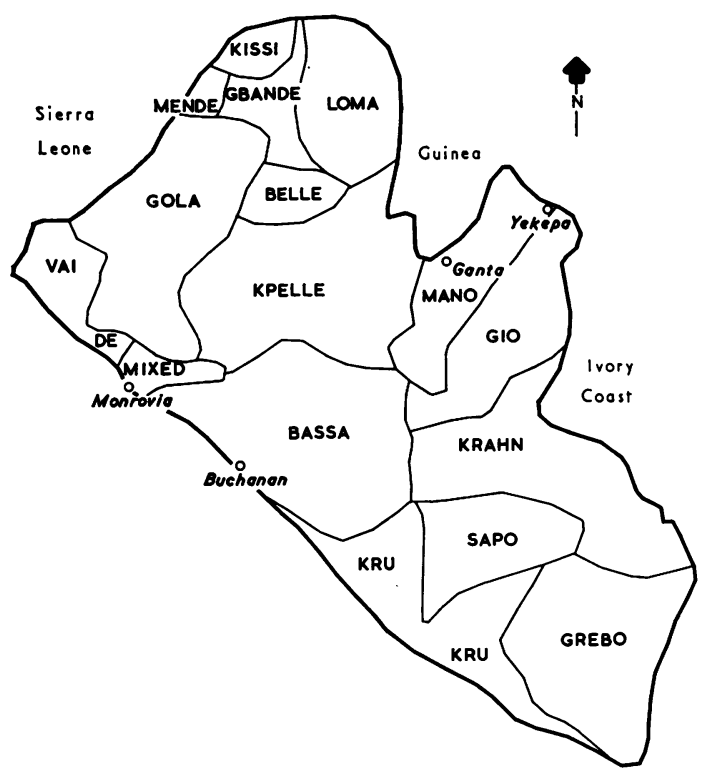

FIG. 1. Tribes of Liberia. A tentative map after Zetterström (1969).

Although incidence figures based on the population in and around Yekepa may not be valid for the country as a whole, in addition to revealing the extent of the local situation, they can be of value in pointing out which tribes or areas may be profitable for a more detailed field survey.

Investigation into prevalence of $\beta$-thalassaemia. Blood samples were collected into di-potassium EDTA but from some of the smaller children capillary samples were collected with the aid of heparinized glass capillary tubing. The individuals sampled in this investigation were divided into four groups.

Group 1 was a total of 407 African children from a primary school in Yekepa. There were 214 boys and 193 girls aged between 5 and 16 years, the majority were between 6 and 11 years. This group was investigated for several reasons. Most were children of Lamco employees; any repeat or further examinations could be made without difficulty and the families were readily available if required. These families reside in an area covered by malaria control and the incidence of parasitaemia in the schoolchildren is known to be very low $2.0 \%$ in 1971) compared with similar groups outside. Finally it was thought that the general state of nutrition would be better than that found in comparable children outside the community, thus minimizing the effect that this may have on $\mathrm{Hb} \mathrm{A}_{2}$ levels. However, K. B. Jakobsen (unpublished data) has found little difference in nutritional status, based on amnio-acid analysis in blood, between these children and a similar group in a nearby town.

Group 2 contained 338 Africans from towns outside the Lamco area. The majority lived within $20 \mathrm{~km}$ of Yekepa and the samples were mainly collected during the Company's bi-annual cholera vaccination programme. However, 102 specimens were collected in the town of Ganta about $70 \mathrm{~km}$ from Yekepa. Just over $50 \%$ of persons sampled were male and 131 (about 39\%), were under 15 years. The youngest child tested was 6 months old, the majority were over 5 years.

Group 3 comprised 301 healthy Africans attending the hospital laboratory for health checks or as blood donors. This group included persons from both inside and outside the Lamco area, some blood donors travelling over $200 \mathrm{~km}$. The great majority, 265 persons, were male and there were 25 children all over 5 years.

Group 4 contained all admissions to the children's ward of Yekepa hospital over a period of about 3 months. There were 245 infants and children of both sexes in this group. The ages ranged from neonates to 14 years, however most were under 3 years. This group was included primarily because it would certainly contain several severe cases of malaria.

Malaria in relationship to $\mathrm{Hb} \mathrm{A}_{2}$ levels. In addition to any persons found to have positive malaria smears in the four groups just described, $\mathrm{Hb} \mathrm{A}_{2}$ levels were estimated on 55 patients admitted to hospital with malaria. Of these 17 were children not falling into group 4 because they were not admitted during the 3month period investigated.

Incidence of $\alpha$-thalassaemia. Screening of neonates for the presence of a significant amount of $\mathrm{Hb}$ Barts seemed the most practical method in view of the limited time available for this part of the study. Blood samples were collected by heel-prick from 350 newborn children. It was simpler to obtain the samples in this way than to rely on the collection of cord bloods at delivery. In addition, levels of $\mathrm{Hb} \mathrm{A}$ and $\mathrm{Hb} \mathrm{S}$ were estimated on samples from 87 sickle-cell heterozygotes.

Haematological and haemoglobin analytical studies. All samples were analysed by cellulose acetate electrophoresis, solubility tests for $\mathrm{Hb} \mathrm{S}$, quantitation of $\mathrm{Hb} \mathrm{A_{2 }}$ and structural variants, and screening for $\mathrm{Hb} F$ by the acid elution technique. In some cases routine haematological studies were performed and where 
appropriate $\mathrm{Hb} \mathrm{F}$ estimations were carried out. All cases except neonates were screened for malarial parasites.

Haematological investigations followed standard techniques (Dacie and Lewis, 1968). Haemolysates were prepared by the methods of Lehmann and Huntsman (1966), and qualitative cellulose acetate electrophoresis was performed as described in Weatherall and Clegg (1972). The samples were analysed routinely in a Tris buffer system, $\mathrm{pH} 8.5$, and a phosphate buffer system, $\mathrm{pH} 6.5$, was used for the differentiation of rapidly migrating haemoglobins including haemoglobin Barts. Solubility tests (Cook and Raper, 1971) were performed on all specimens showing $\mathrm{Hb} S$ on electrophoresis. The tubes were read after standing some hours to avoid anomolous results caused by high globulin levels in the samples (Willcox, 1973).

$\mathrm{Hb} \mathrm{A_{2 }}$ concentrations were estimated on all samples, except those from neonates, by the method of Weatherall et al (1971). Estimations on samples from 128 normal Europeans gave values of between 1.5 and $3.2 \%$ (mean $2.37 \%$, SD $0.38 \%$ ) and 40 estimations on a single sample ranged from 1.78 to $2.24 \%$ (SD $0.14 \%$ ). In an investigation of family members of thalassaemia homozygotes (Willcox et al, 1975) the lowest value of $\mathrm{Hb} \mathrm{A}_{2}$ found in 25 persons with $\beta$-thalassaemia trait was $3.8 \%$ and this level was used in this study as the lowest significant value. To allow for slight variations in technique the uppermost limit of normal was taken as $3.4 \%$. During this investigation, and on other occasions, it proved essential to estimate $\mathrm{Hb} \mathrm{A}_{2}$ levels on all specimens as recognition of those samples with raised values by visual inspection alone was found to be unreliable as a screening procedure. This was also the experience of Weatherall et al (1971).

Structural haemoglobin variants were also estimated by this method. All estimations including $\mathrm{Hb} \mathrm{A}_{2}$ levels were made within 3 days of preparing the haemolysate.

The method of Nierhaus and Betke (1968) was used for screening smears for fetal haemoglobin. Quantitative $\mathrm{Hb} F$ estimations were performed as described by Pembrey, McWade, and Weatherall (1972). To establish the significant level of $\mathrm{Hb} F$ under the conditions of the survey estimations were made on samples from healthy Europeans. Three out of 84 blood samples from adults had values over $1 \%$, the highest was $1.2 \%$. Blood from 60 children aged between 2 and 14 years were all below $1.5 \%$ except for one outlier of $1.7 \%$. To allow for variations in technique and other factors it was decided to set the significant level for adults at $1.5 \%$ but in the case of the schoolchildren in group 1 to disregard values below $2 \%$.

Malaria smears were examined as thick-drop preparations stained unfixed by Giemsa stain. When necessary to aid in identification of parasite types, thin smears were examined after staining by May-Grünwald-Giemsa technique.

\section{Results}

$\beta$-Thalassaemia survey. The proportions of the various haemoglobin types identified in each group are shown in Table $I$ and Fig. 2 shows the distribution of $\mathrm{Hb} \mathrm{A}_{2}$ levels in the schoolchildren in group 1. This type of distribution was typical of all groups in the survey.

Haemoglobin type $A / A$. The $\mathrm{Hb} \mathrm{\textrm {A } _ { 2 }}$ levels were up to $3.7 \%$ and the mean of those falling in the normal range was $2.43 \%$ (SD $0.46 \%$ ). Fourteen samples classified as haemoglobin type A/A had levels of $\mathrm{Hb} \mathrm{A}_{2}$ above the upper limit of normal but not raised sufficiently to be classified as haemoglobin type $\mathrm{A} / \beta$-thalassaemia.

Haemoglobin type A/B-thalassaemia. With one

TABLE I

COMPARISON OF HAEMOGLOBIN TYPES IN INDIVIDUALS FROM GROUPS 1-4

\begin{tabular}{|c|c|c|c|c|}
\hline \multirow{2}{*}{ Hb Type } & \multicolumn{4}{|c|}{ Group } \\
\hline & 1 & 2 & 3 & 4 \\
\hline 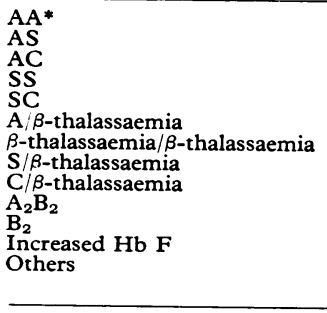 & $\begin{array}{rr}309 & (75.9 \%) \\
31 & (7.6 \%) \\
1 & (0.2 \%) \\
1 & (0.2 \%) \\
\frac{43}{43} & (10.6 \%) \\
2 & (0.5 \%) \\
1 & (0.2 \%) \\
1 & (0.2 \%) \\
6 & (1.5 \%) \\
\frac{12}{12} & (2.9 \%) \\
& \end{array}$ & $\begin{aligned} & 292(86.4 \%) \\
& 12(3.5 \%) \\
& 4(1.2 \%) \\
&= \\
& 17(5 \%) \\
& 1(0.3 \%) \\
& 1(0.3 \%) \\
& \frac{2}{2}(0.6 \%)(0.6 \%) \\
& 3 \ddagger(1.3 \%) \\
& 4(1.2 \%) \\
&(\mathrm{Hb} \mathrm{N}) \\
&\end{aligned}$ & \begin{tabular}{|cc}
220 & $(73 \%)$ \\
24 & $(8 \%)$ \\
$\frac{2}{2}$ & $(0.7 \%)$ \\
$\frac{35}{35}$ & $(11.6 \%)$ \\
$\frac{1}{2}$ & $(0.3 \%)$ \\
$\frac{8}{8}$ & $(0.7 \%)$ \\
$\frac{7}{7}$ & $(2.6 \%)$ \\
2 & $(0.7 \%)$ \\
(Hb K and Flatbush)
\end{tabular} & $\begin{array}{cc}189+ & (77.1 \%) \\
27 & (11 \%) \\
\frac{3}{3} & (1.2 \%) \\
1 & (0.4 \%) \\
17 & (6.9 \%) \\
2 & (0.8 \%) \\
\frac{-}{3} & (1.2 \%) \\
1 & (0.4 \%) \\
* * & (0.8 \%) \\
2 & (0.8 \%) \\
\text { (Hb N and Barts) }\end{array}$ \\
\hline Total & 407 & 338 & 301 & 245 \\
\hline
\end{tabular}

Increased $\mathrm{Hb} \mathrm{F}$ signifies a slight increase in this $\mathrm{Hb}$ with an otherwise normal pattern.

* AA includes specimens with $\mathrm{Hb} \mathrm{A}_{2}$ values above the upper limit of normal but not falling into $\mathrm{A} / \beta$-thalassaemia.
+ Includes 10 neonates with a normal newborn pattern.

$\ddagger$ Hb F values not estimated on 102 samples from Ganta.

** Hb F not assessed in this group. 


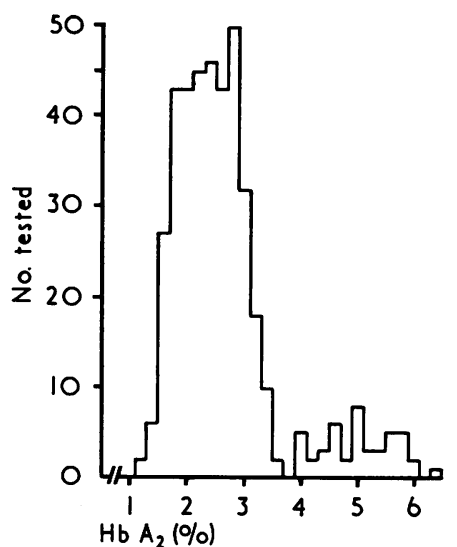

Fig. 2. Percentage distribution of $\mathrm{Hb} \mathrm{A}_{2}$ levels in schoolchildren from group 1.

exception, described below, the $\mathrm{Hb} \mathrm{\textrm {A } _ { 2 }}$ levels of samples falling into this classification were from 3.8 to $7.6 \%$ (mean $5.3 \%$, SD $0.49 \%$ ). One sample from a child was heterozygous for haemoglobins $A_{2}$ and $B_{2}$. Both variants, present in approximately equal proportions and estimated together, totalled $4.9 \%$. The distribution of $\mathrm{Hb} \mathrm{A}_{2}$ and $\mathrm{Hb} F$ values of phenotype $A / \beta$-thalassaemia is shown in Fig. 3. The higher levels of $\mathrm{Hb} \mathrm{F}$ are from children, the highest being from a 6-month-old child. The highest value in an adult is $4.8 \%$. Table II shows routine haematological values from 15 people classified as this haemoglobin type; the results are consistent with $\beta$-thalassaemia trait. All malaria smears of these individuals were negative. The exception was a young adult woman having a $\mathrm{Hb} \mathrm{F}$ value of $7.2 \%$ distributed heterogeneously in the red cells, $\mathrm{Hb} \mathrm{\textrm {A } _ { 2 }}$ of $1.7 \%$, and a blood picture consistent with thalassaemia trait

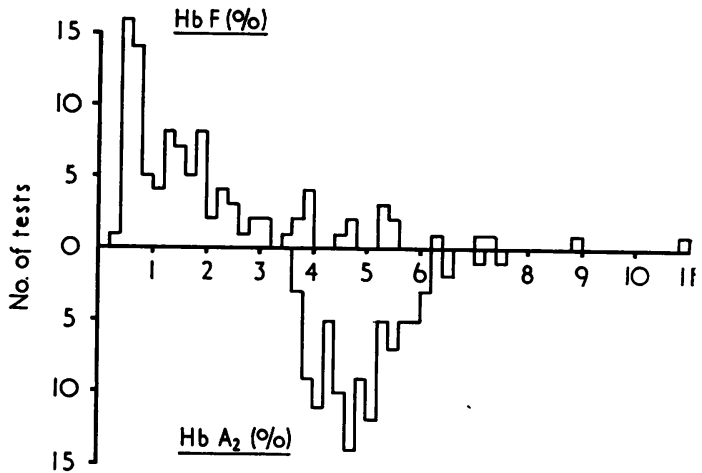

FIG. 3. Percentage distribution of $\mathrm{Hb} \mathrm{A}_{2}$ and $\mathrm{Hb} F$ levels in $\beta$-thalassaemia heterozygotes.

(Table II). She was considered to be heterogeneous for $\delta \beta$-thalassaemia; these $\mathrm{Hb} \mathrm{F}$ and $\mathrm{Hb} \mathrm{A}_{2}$ values are not included in Figure 3.

Haemoglobin type $\beta$-thalassaemia/ $\beta$-thalassaemia. The two children from group 4 with this classification were clinically cases of thalassaemia major, the diagnosis being supported by family studies. These are reported in detail elsewhere as are further investigations on one of the schoolchildren in group 1 (Willcox et al, 1975). The $\mathrm{Hb} \mathrm{A}_{2}$ values of the other three persons with this haemoglobin type were $4.28,4.66$, and $6.2 \%$ with $\mathrm{Hb} F$ levels of 31.4 , 24.4 , and $37.2 \%$, respectively, distributed, in each case, heterogeneously amongst the red cells. Two persons were adults and one of these, a young Mano woman, had a 12-month-old child with the pattern of sickle-cell thalassaemia. The father had sicklecell trait.

TABLE II

ELECTROPHORETIC AND HAEMATOLOGICAL FINDINGS IN 15 INDIVIDUALS CLASSIFIED AS A/ $\beta$-THALASSAEMIA

\begin{tabular}{|c|c|c|c|c|c|c|c|c|c|c|c|}
\hline Tribe & $\begin{array}{c}\text { Age } \\
\text { (years) }\end{array}$ & Sex & $\underset{(\%)}{\mathbf{H b}_{(\%)} \mathbf{A}_{2}}$ & $\underset{(\%)}{\mathbf{H b}} \mathbf{F}$ & $\underset{(\mathrm{g} / \mathrm{al})}{\mathbf{H b}}$ & $\underset{\left(\times 10^{12} / 1\right)}{\text { RBC }}$ & PCV & $\underset{(\mathrm{pg})}{\mathrm{MCH}}$ & $\underset{(\mathrm{fl})}{\mathrm{MCV}}$ & $\underset{(\mathrm{g} / \mathrm{dl})}{\operatorname{MCHC}}$ & $\underset{\text { Morphology* }}{\text { Red Cell }}$ \\
\hline $\begin{array}{l}\text { Mano } \\
\text { Loma } \\
\text { Grebo } \\
\text { Mano } \\
\text { Grebo } \\
\text { Mano } \\
\text { Grebo } \\
\text { Bassa } \\
\text { Mano } \\
\text { Kru } \\
\text { Kpelle } \\
\text { Gio } \\
\text { Gio } \\
\text { Gio } \\
\text { Gio }\end{array}$ & $\begin{array}{l}7 \\
6 \\
6 \\
\text { A(dult) } \\
\text { A } \\
\text { A } \\
\text { A } \\
\text { A } \\
\text { A } \\
\text { A } \\
\text { A } \\
\text { A } \\
\text { A } \\
\text { A } \\
\text { A }\end{array}$ & $\begin{array}{l}F \\
M \\
F \\
M \\
F \\
M \\
M \\
M \\
F \\
M \\
M \\
M \\
M \\
F \\
F\end{array}$ & $\begin{array}{l}5.6 \\
5.35 \\
5.17 \\
4.78 \\
4.73 \\
4.14 \\
5.15 \\
4.79 \\
4.76 \\
4.27 \\
4.66 \\
4.64 \\
4.33 \\
4.0 \\
1.7\end{array}$ & $\begin{array}{l}5.55 \\
1.68 \\
4.5 \\
2.71 \\
4.8 \\
1.55 \\
1.24 \\
3.0 \\
2.0 \\
0.8 \\
4.0 \\
2.42 \\
0.8 \\
1.56 \\
7.15\end{array}$ & $\begin{array}{l}13.4 \\
11.5 \\
12.3 \\
15.6 \\
13.4 \\
14.5 \\
16.6 \\
15.4 \\
11.2 \\
15.0 \\
14.8 \\
13.1 \\
14.2 \\
12.2 \\
14.6\end{array}$ & $\begin{array}{l}5.2 \\
6.1 \\
5.5 \\
6.2 \\
4.7 \\
6.0 \\
7.0 \\
6.1 \\
5.5 \\
6.25 \\
5.5 \\
6.1 \\
6.2 \\
5.9 \\
6.4\end{array}$ & $\begin{array}{l}0.40 \\
0.38 \\
0.34 \\
0.45 \\
0.38 \\
0.47 \\
0.47 \\
0.46 \\
\overline{0.47} \\
0.43 \\
0.41 \\
0.43 \\
0.37 \\
0.50\end{array}$ & $\begin{array}{l}25.8 \\
18.8 \\
22.4 \\
25.2 \\
28.5 \\
24.2 \\
23.7 \\
25.2 \\
20.3 \\
24.0 \\
26.9 \\
21.5 \\
22.9 \\
20.7 \\
22.8\end{array}$ & $\begin{array}{l}76.9 \\
62.3 \\
61.8 \\
72.6 \\
80.8 \\
78.3 \\
67.1 \\
75.4 \\
75.2 \\
78.2 \\
67.2 \\
69.3 \\
62.7 \\
78.1\end{array}$ & $\begin{array}{l}33.5 \\
30.3 \\
36.2 \\
34.6 \\
35.3 \\
30.8 \\
35.3 \\
33.4 \\
\overline{31.9} \\
34.4 \\
31.9 \\
33.0 \\
32.9 \\
29.2\end{array}$ & $\begin{array}{c}(+) \\
(+) \\
+ \\
(+) \\
+ \\
(+) \\
+ \\
(+) \\
+ \\
(+) \\
(+) \\
+ \\
(+) \\
(+) \\
+\end{array}$ \\
\hline
\end{tabular}

* $(+)=$ slight morphological abnormalities of erythrocytes; + more marked abnormalities. 
TABLE III

TRIBAL DISTRIBUTION OF SICKLE CELL, Hb C, AND $\beta$-THAIASSAEMIA TRAITS AND $\delta$-CHAIN VARIANTS FROM LIBERIANS IN GROUPS $1-4$ WHEN TRIBAL STATUS WAS CLEAR

\begin{tabular}{|c|c|c|c|c|c|}
\hline Tribe & Total & AS & AC & A/ $\beta$-Thalassaemia & $\delta$-Chain Variant \\
\hline $\begin{array}{l}\text { West Atlantic Group } \\
\text { Gola } \\
\text { Gissi }\end{array}$ & $\begin{array}{l}12 \\
31\end{array}$ & $\begin{array}{l}1(8.3 \%) \\
7(28.5 \%)\end{array}$ & $\overline{1}(3.2 \%)$ & - & - \\
\hline $\begin{array}{l}\text { Mande-tan Group } \\
\text { Mandingo } \\
\text { Vai }\end{array}$ & $\begin{array}{l}97 \\
15\end{array}$ & $\begin{array}{r}22(22.7 \%) \\
4(26.7 \%)\end{array}$ & $\underline{3}^{3}(3.1 \%)$ & - & $\underline{2}^{*}(2.1 \%)$ \\
\hline $\begin{array}{l}\text { Mande-fu Group } \\
\text { Mano } \\
\text { Gio } \\
\text { Kpelle } \\
\text { Loma } \\
\text { Gbande }\end{array}$ & $\begin{array}{r}482 \\
98 \\
112 \\
57 \\
10\end{array}$ & $\begin{array}{r}14(2.9 \%) \\
3(3.0 \%) \\
11(9.8 \%) \\
8(14.0 \%) \\
1(10.0 \%)\end{array}$ & $\begin{array}{l}1(0.2 \%) \\
-\end{array}$ & $\begin{array}{c}42(8.7 \%) \\
11(11.2 \%) \\
6(5.3 \%) \\
8(14.0 \%) \\
-\end{array}$ & $\begin{array}{ll}3 & (0.7 \%) \\
1 & (1.0 \%) \\
3 & (2.7 \%) \\
- & \end{array}$ \\
\hline $\begin{array}{l}\text { Kru Group } \\
\text { Krahn } \\
\text { Grebo } \\
\text { Bassa } \\
\text { Kru }\end{array}$ & $\begin{array}{r}46 \\
107 \\
118 \\
40\end{array}$ & $\begin{aligned} 1 & (2.2 \%) \\
3 & (2.8 \%) \\
10 & (8.5 \%) \\
3 & (7.5 \%)\end{aligned}$ & E & $\begin{array}{r}7(15.2 \%) \\
12(11.2 \%) \\
15(12.7 \%) \\
9(22.5 \%)\end{array}$ & $\begin{array}{l}2(4.3 \%) \\
5+(4.7 \%) \\
4 \quad(3.4 \%) \\
2 \quad(5.0 \%)\end{array}$ \\
\hline Total & 1225 & $88(7.2 \%)$ & $5(0.4 \%)$ & $110(9.0 \%)$ & $22(1.8 \%)$ \\
\hline
\end{tabular}

* These two individuals were homozygous for $\mathrm{Hb}_{\mathbf{2}}$.

+ Contained one homozygote for $\mathrm{Hb} \mathrm{B}_{2}$.

Haemoglobin type $S$ or $C / \beta$-thalassamia. In the samples so classified the $\beta$-chain variant was between $60 \%$ and $70 \%$ of total haemoglobin with a variable amount of $\mathrm{Hb} \mathrm{F}$, the highest, in the infant just mentioned, being $31 \%$; all the others were below $9 \%$. The $\mathrm{Hb} \mathrm{A}_{2}$ values in the $\mathrm{S} / \beta$-thalassaemia group were between 3.4 and $6.2 \%$.

Other haemoglobin types with $\beta$-chain variants. Solubility tests were performed on all samples showing $\mathrm{Hb} \mathrm{S}$ by electrophoresis; all were positive. Those showing a major haemoglobin component in the position of $\mathrm{Hb} \mathrm{A}_{2}$ were presumed to be $\mathrm{HbC}$ carriers although $\mathrm{Hb} \mathrm{O}_{\text {Arabia }}$ may well exist in this population at low frequency.

'Fast' haemoglobins have been described previously in Liberia (Robinson et al, 1956) and of the examples encountered here five behaved electrophoretically in a similar manner to Liberia I ( $\mathrm{Hb} \mathrm{N}$ of Ager and Lehmann, 1958). Four of these were discovered in persons from the same town. One other 'fast' haemoglobin behaved like Hb K (Liberia II of Robinson et al, 1956) and was present at a concentration of over $50 \%$, similar to one of the examples examined by Ager and Lehmann (1958). This last is under study but unfortunately insufficient remained of the other specimens for further investigation.

$\delta$-Chain variants. The majority of these were electrophoretically similar to $\mathrm{Hb} \mathrm{B}_{2}$. One however had the same mobility of $\mathrm{Hb} S$ and was presumed to be an example of $\mathrm{Hb}$ Flatbush. Three samples were homozygous for $\mathrm{Hb} \mathrm{B}_{2}$. The levels of $\delta$-chain variants, estimated together with $\mathrm{Hb} \mathrm{A}_{2}$ if heterozygous, were all within the normal limits for $\mathrm{Hb} \mathrm{A}_{2}$ alone with the exception of the child heterozygous for $\mathrm{Hb} \mathrm{A}_{2}$ and $\mathrm{Hb} \mathrm{B}_{2}$ described under haemoglobin type $\mathrm{A} / \beta$-thalassaemia.

Raised $\mathrm{Hb} \mathrm{F}$ with normal levels of $\mathrm{Hb} \mathrm{A}_{2}$. One of these thought to be heterozygous $\delta \beta$-thalassaemia has been described above. The highest levels of the remaining specimens were 6.4 and $4.2 \%$, both from 10-year-old children. All other values were below $3.2 \%$. Only specimens from groups 1,2 , and 3 were classified into this haemoglobin type because of the difficulties of assessing the significance of $\mathrm{Hb} \mathrm{F}$ levels in infants and small children. However, a small proportion of the $\mathrm{Hb} F$ values in group 4 did appear to be above the trend for the particular age. No examples of hereditary persistence of fetal haemoglobin were encountered.

Tribal distribution of sickle cell, $\mathrm{Hb} \mathrm{C}$, and $\beta$-thalassaemia traits and $\delta$-chain variants. (Table III.) The total number of cases is lower than in Table I because only those specimens from Liberians in whom the tribal status was clear are shown. The distribution of sickle-cell trait is similar to that found by Livingstone (1958) except in the case of the Kru tribe in which a small sample containing two sibs with sickle-cell trait gives too high a frequency. In a larger sample, investigating 
TABLE IV

SICKLE-CELI AND B-THALASSAEMIA TRAITS RELATED TO MAIN DIAGNOSIS IN 211 CHILDREN ADMITTED TO HOSPITAL

\begin{tabular}{l|r|r|r}
\hline \multicolumn{1}{c|}{ Main Diagnosis } & $\begin{array}{r}\text { Total } \\
\text { No. }\end{array}$ & AS & A/ $\beta$-Thalassaemia \\
\hline Malaria & 49 & 4 & 2 \\
Bronchopneumonia & 35 & 4 & 8 \\
Acute bronchitis & 18 & 3 & 2 \\
Typhoid fever & 4 & 2 & - \\
Salmonella enteritis & 3 & - & - \\
Shigella & 3 & - & - \\
Diarrhoea, non-specific & 20 & 4 & 1 \\
Parasitic infestation & 15 & 1 & - \\
Malnutrition & 6 & - & 2 \\
Tuberculosis & 2 & - & 17 \\
Malignancy & 52 & -9 & 27 \\
Miscellaneous & 211 & 27 & \\
\hline Total & & & \\
\hline
\end{tabular}

sickling rates only, the Kru were found to have a frequency of $1.25 \%$ sickle-cell trait (unpublished data).

Relation of $\beta$-thalassaemia trait to disease. Table IV shows the relationship of the main diagnosis in 211 children to sickle cell and $\beta$-thalassaemia trait. There are a significant number of children with $\beta$-thalassaemia trait in this sample suffering from bronchopneumonia $\left(\chi^{2}=10.128\right.$ for 1 degree of freedom, $0.01>p>0.001)$ whereas the number of those with malaria are not significant $\left(x^{2}=0.752\right.$ for 1 degree of freedom, $\left.0.5>p>0.3\right)$. However, the numbers involved are small and many more cases are needed before any definite conclusions can be reached.

Effect of malaria on $\mathrm{Hb} \mathbf{A}_{2}$ levels. In all, 169 persons had positive malaria smears and of these 11 (about $6 \%$ ) had $\mathrm{Hb} \mathrm{A}_{2}$ levels at a level normally found in $\beta$-thalassaemia trait and one more had a level above the top limit of normal but not in the $\beta$-thalassamia range. Fig. 4 shows the distribution of $\mathrm{Hb} \mathrm{A}_{2}$ in persons with positive malaria smears. There was no significant difference between the proportion of specimens having raised $\mathrm{Hb} \mathrm{\textrm {A } _ { 2 }}$ levels with positive smears and those with negative $\left(\chi^{2}=0.719\right.$ for 1 degree of freedom, $\left.0.5>p>0.3\right)$. Of the persons with positive smears 104 were clinical cases of malaria and seven of these (about $6.7 \%$ ) had raised $\mathrm{Hb} \mathrm{A}_{2}$ values. The remaining 64 persons, four (6.2\%) of whom had elevated $\mathrm{Hb} \mathrm{A}_{2}$ levels, were for the most part asymptomatic. Thus the frequency of raised $\mathrm{Hb} \mathrm{A}_{2}$ levels in actual cases of malaria and in carriers was identical.

The majority of infections were caused by Plasmodium falciparum; $P$. malariae was responsible for $15 \%$, and $10 \%$ were mixed infections. $P$. vivax

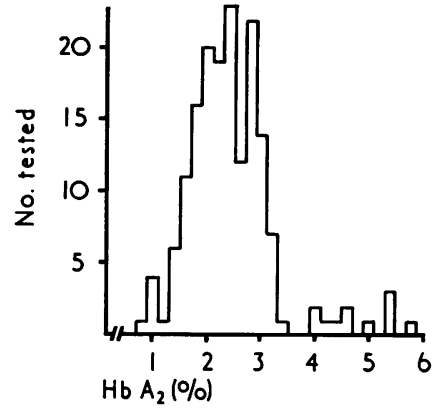

Fig. 4. Percentage distribution of $\mathbf{H b ~} \mathrm{A}_{2}$ levels in subjects with positive malaria smears.

and $P$. ovale were each found on one occasion (Table V).

Follow-up studies on some of the patients after the infection was cleared would have been valuable but repeat $\mathrm{Hb} \mathrm{A_{2 }}$ estimations were only possible on four children all of whom showed no appreciable difference in levels at the time of infection and between two weeks and one month afterwards. Table VI gives the result of haemoglobin analysis and some haematology on these and other cases of malaria with high levels of $\mathrm{Hb} \mathrm{A}_{\mathbf{2}}$.

\section{$\alpha$-Thalassaemia investigation.}

Neonates. The haemoglobin patterns of samples from newborn children are shown in Table VII. Exactly $10 \%$ have a significant amount of $\mathrm{Hb}$ Barts, ie, more than $1 \%$. The highest value was $10 \%$. There were 10 pairs of twins; two pairs had more than $1 \mathrm{~g} / \mathrm{dl} \mathrm{Hb}$ Barts in one twin and not in the other. In one instance the twin without $\mathrm{Hb}$ Barts was heterozygous for $\mathrm{Hb} \mathrm{S}$. It was not known if these twins were uniovular. The proportion of children showing a newborn pattern with $\mathrm{Hb} \mathrm{S}$ was $5.1 \%$. Although just over $2 \%$ lower than the proportion of sickle-cell trait found in older persons in the survey, the difference was not significant $\left(\chi^{2}=1.938\right.$ for 1 degree of freedom, $0.2>p>0.1$ ). No further examinations were made on these infants or their parents.

Sickle-cell heterozygotes. Figure 5 shows the distribution of $\mathrm{Hb} \mathrm{A}$ levels in 87 sickle-cell heterozygotes. The mean was $69.5 \%$ (SD, 3.2\%). The distribution shows a skew with a block of values in the $75 \%$ to $81 \%$ range.

\section{Discussion}

The results show a high rate of $\beta$-thalassaemia trait in northern Liberia. The figure is about $9 \%$ 
TABLE V

INCIDENCE OF MALARIA IN THE NIMBA AREA OF LIBERIA (1972)

\begin{tabular}{|c|c|c|c|c|c|}
\hline \multirow{2}{*}{ Location } & \multicolumn{2}{|c|}{ Total Examined } & \multicolumn{2}{|c|}{ Positive } & \multirow{2}{*}{ Total Positive } \\
\hline & Adults & Children & Adults & Children & \\
\hline Yekepa (Lamco) & 93 & 537 & $5(5.4 \%)$ & $18\left(3.4_{0}^{\circ}\right)$ & $3.6 \%$ \\
\hline $\begin{array}{l}\text { Lugbeh } \\
\text { Blay } \\
\text { New Yekepa } \\
\text { New Bapa } \\
\text { Bhapa } \\
\text { Unification Camp }\end{array}$ & $\begin{array}{l}13 \\
47 \\
27 \\
55 \\
57 \\
80\end{array}$ & $\begin{array}{r}5 \\
37 \\
106 \\
15 \\
80 \\
79\end{array}$ & $\begin{array}{c}1(7.7 \%) \\
4(8.5 \%) \\
10(37.0 \%) \\
7(9.1 \%) \\
15(26.3 \%) \\
18(22.5 \%)\end{array}$ & $\begin{array}{l}2(40.0 \%) \\
12(32.4 \%) \\
71(67.0 \%) \\
10(66.7 \%) \\
29(36.2 \%) \\
23(29.1 \%)\end{array}$ & $\begin{array}{l}16.7 \% \\
19.0 \% \\
60.9 \% \\
24.2 \% \\
32.1 \% \\
25.7 \%\end{array}$ \\
\hline Total (excluding Lamco) & 279 & 322 & $55(19.7 \%)$ & $147(45.6 \%)$ & $33.6 \%$ \\
\hline
\end{tabular}

TABLE VI

HAEMATOLOGICAL VALUES AND HAEMOGLOBIN ANALYSIS ON $\beta$-THALASSAEMIA HETEROZYGOTES WITH MALARIA

\begin{tabular}{|c|c|c|c|c|c|c|c|c|}
\hline Tribe & Age & Sex & Malaria Type & $\begin{array}{c}\mathbf{H b} \mathbf{A}_{\mathbf{2}} \\
(\%)\end{array}$ & $\underset{(\%)}{\mathbf{H b}} \mathbf{F}$ & $\mathrm{Hb}(\mathrm{g} / \mathrm{dl})$ & $\underset{(\mathrm{g} / \mathrm{dl})}{\mathrm{MCHC}}$ & $\underset{\text { Morphology }}{\text { Red Cell }}$ \\
\hline $\begin{array}{l}\text { Krahn } \\
\text { Krahn } \\
\text { Grebo } \\
\text { Mano } \\
\text { Gio } \\
\text { Bassa } \\
\text { Bassa } \\
\text { Kpelle } \\
\text { Kpelle }\end{array}$ & $\begin{array}{r}4 \\
1 \\
1 \\
3 \\
5 \\
\text { A } \\
\text { A } \\
10 \\
8\end{array}$ & $\begin{array}{l}M \\
F \\
F \\
M \\
F \\
F \\
F \\
M \\
M\end{array}$ & $\begin{array}{l}\text { Falciparum } \\
\text { Falciparum } \\
\text { Falciparum } \\
\text { Falciparum } \\
\text { Falciparum } \\
\text { Falciparum } \\
\text { Malariae } \\
\text { Falciparum } \\
\text { Falciparum }\end{array}$ & $\begin{array}{l}4.23(4.6)^{*} \\
4.05(4.0) \\
3.95 \\
4.1(4.0) \\
5.37(4.9) \\
3.9 \\
4.7 \\
5.95 \\
5.38\end{array}$ & $\begin{array}{l}5.64 \\
2.3 \\
1.26 \\
2.2 \\
4.7 \\
5.5 \\
3.2 \\
4.85 \\
0.8\end{array}$ & $\begin{array}{r}7.2 \\
8.0 \\
9.0 \\
8.2 \\
11.0 \\
8.4 \\
13.0 \\
12.2 \\
11.6\end{array}$ & $\begin{array}{l}28 \\
32.1 \\
27.2 \\
- \\
27 \\
32 \\
29.8 \\
33.2\end{array}$ & $\begin{array}{l}++ \\
+ \\
+ \\
++ \\
++ \\
+ \\
+ \\
(+) \\
(+)\end{array}$ \\
\hline
\end{tabular}

* Values in parentheses indicate levels estimated after the infection had cleared.

$+(+)=$ slight red cell abnormalities;,$+++=$ more marked abnormalities.

TABLE VII

HAEMOGLOBIN PATTERNS OF NEWBORN CHILDREN

\begin{tabular}{|c|c|c|c|c|c|c|c|c|}
\hline \multirow{2}{*}{$\begin{array}{c}\text { Normal } \\
\text { New- } \\
\text { born } \\
\text { Pattern }\end{array}$} & \multirow{2}{*}{ Trace } & \multicolumn{3}{|c|}{ Hb Barts } & \multirow{2}{*}{$\mathbf{S}$} & \multirow{2}{*}{ C } & \multirow{2}{*}{$s+C$} & \multirow{2}{*}{ Total } \\
\hline & & $1-3 \%$ & $4-6 \%$ & $7-10 \%$ & & & & \\
\hline 245 & 48 & 25 & 7 & 3 & 18 & 3 & 1 & 350 \\
\hline
\end{tabular}

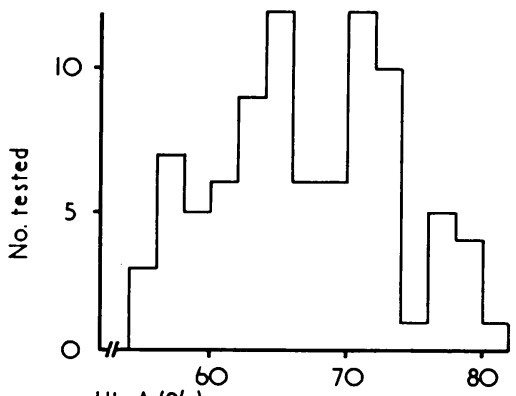

$\mathrm{Hb}$ A (\%)

Fig. 5. Percentage distribution of $\mathrm{Hb} \mathrm{A}$ in sickle-cell heterozygotes. for the population as a whole but the incidence varies widely according to tribes. $\delta \beta$-Thalassaemia was also found but appears to be at low frequency. $\delta$-Chain variants are fairly common but show no indication of having a tribal distribution.

It is not clear whether the high rate of $\beta$-thalassaemia trait in Yekepa is indicative of a large incidence throughout Liberia. Only properly conducted surveys in other parts of the country can show this but in support of the case for a high rate elsewhere is that much of the population sampled is not indigenous to Yekepa. However, although the individuals tested were chosen as much at random as possible, to a certain extent they selected themselves in that the need for employment brought them to the district, or that they had a relative in hospital, or, in the case of the persons in group 2, that they wanted to be vaccinated and were also willing to have a blood sample taken.

Consequently there are many family members in the groups and this may have influenced the results, overstating the frequency of thalassaemia. It is also possible, though not so likely, that any bias may be in the other direction. It must be emphasized 
however that no $\beta$-thalassaemia heterozygote relatives of the homozygotes appear in the survey figures. This was more due to chance than design; they did not fall into any of the groups tested. However, even allowing for bias, the data show that $\beta$ thalassaemia must exist over much of Liberia and at a fairly high incidence in some tribes judged by the number of homozygotes discovered.

The tribal distribution of $\beta$-thalassaemia trait is of interest. The highest incidence was found in the tribes speaking a Kru tongue and who mainly come from south-east Liberia. These tribes, except in certain districts of the Bassa (Livingstone, 1958), have a very low incidence of $\mathrm{Hb} \mathrm{S}$. However, Neel et al (1961) found the greatest number of raised $\mathrm{Hb} \mathrm{A}_{2}$ levels in samples from tribes located in northwest Liberia where the sickle-cell rate is highest, and very few increased $\mathrm{Hb} \mathrm{A}_{2}$ values from southeast Liberia. Unfortunately several of the tribes from north-west Liberia were not adequately represented in the present survey but the results in the Kpelle for example are in agreement with the earlier data. The differences in findings reported for the tribes originating in south-east Liberia may be explained in part by the different conditions under which the two surveys were conducted, the most important being that whilst here all $\mathrm{Hb} \mathrm{\textrm {A } _ { 2 }}$ levels were estimated, in the earlier work a total of only 50 estimations were made after screening by scanning of some 500 electrophoretic patterns. However, previous authors emphasized that they considered that the method they used for screening for elevated $\mathrm{Hb} \mathrm{A_{2 }}$ levels was not satisfactory and their estimate of thalassaemia trait used other criteria in addition to $\mathrm{Hb} \mathrm{A_{2 }}$ levels.

In those tribes where $\beta$-thalassaemia and sicklecell traits are both reported to be present at a high rate there is not at present sufficient evidence to say whether they exist side by side or in breeding isolates, being mutually exclusive as are haemoglobins $S$ and C elsewhere in West Africa (Allison, 1957). Livingstone (1960) found isolates of low sickling rates in most tribes with a high incidence of $\mathrm{Hb} \mathrm{S}$ and in one district of the Bassa tribe reported by him as having a zero $\mathrm{Hb} \mathrm{S}$ rate, two thalassaemia homozygotes and several heterozygotes have been discovered (unpublished observations). If thalassaemia and sickling genes are introduced into the same population, the survival of one or the other will depend on the relative fitness of the homozygotes and heterozygotes for these genes and their interaction. With $\mathrm{Hb} \mathrm{S}$ homozygotes having for practical purposes a fitness of zero and the higher fitness of the type of $\beta$-thalassaemia homozygote encountered here, it is possible to envisage the $\beta$ - thalassaemia gene thriving at the expense of the $\mathrm{Hb} S$ gene over many generations. On the other hand, if the apparent susceptibility of children with $\beta$-thalassaemia trait to respiratory disorders is indicative of a higher fitness ratio for $\mathrm{Hb} S$ heterozygotes, $\mathrm{Hb} \mathrm{S}$ may well eventually replace $\beta$-thalassaemia in Liberia. Livingstone (1960) has already postulated the 'wave of advance' of the sickle cell gene throughout Liberia although the effect of thalassaemia on the spread of $\mathrm{Hb} \mathrm{S}$ was not considered, the former having at that time only just been described in Liberia.

It is possible that the estimate of $9 \%$ for $\beta$-thalassaemia trait in Yekepa is too low. Some of the individuals with $\mathrm{Hb} \mathrm{A_{2 }}$ levels intermediate between the $\beta$-thalassaemia and normal ranges may in fact have thalassaemia trait with $\mathrm{Hb} \mathrm{\textrm {A } _ { 2 }}$ levels affected by iron deficiency (Wasi, Disthasongchan, and $\mathrm{Na}-$ Nakorn, 1968). Cases have been seen in Yekepa of nutritional anaemia in pregnancy with associated iron deficiency in which the $\mathrm{Hb} \mathrm{\textrm {A } _ { 2 }}$ levels, initially low, have risen to the thalassaemia level after treatment, the condition being confirmed by other studies (unpublished obervations). Similarly, the specimens with slightly raised $\mathrm{Hb} F$ values may represent a thalassaemia phenotype although it is more probable that these were examples of the 'Swiss' type of hereditary persistence of fetal haeglobin. All populations appear to have a small proportion of individuals with slightly raised levels of fetal haemoglobin and Weatherall et al (1971) found up to $3 \%$ showing this feature in their investigation on various African populations.

Infection with malarial parasites appears to have had little if any effect on the results in this study. Weatherall et al (1971) came to the same conclusion and indeed, if malaria, or at least the varieties caused by $P$. falciparum and $P$. malariae, does alter the $\mathrm{Hb} \mathrm{A_{2 }}$ level significantly one would have expected there to be a higher rate of $\beta$-thalassaemia trait reported than the $0.2 \%$ they found in 574 Nigerians.

The results of the $\alpha$-thalassaemia section are in general agreement with those reported previously from West Africa (Hendrickse, 1965; Oudart et al, 1968; Esan, 1970; Weatherall et al, 1971). However, there is some doubt about the significance of Hb Barts in the African infant and Esan (1970) has suggested that the presence of this haemoglobin may be due not to $\alpha$-thalassaemia but some other at present unknown cause. Also low levels of $\mathrm{Hb} \mathrm{S}$ and $\mathrm{Hb} \mathrm{C}$ in the heterozygotes for these variants may be due to iron deficiency (Levere, Lichtman, and Levine, 1964) or megaloblastic anaemia (Heller et al, 1963) as well as $\alpha$-thalassaemia. Nonetheless, the 
studies of Weatherall (1963) and Oudart et al (1968) show that a mild form of $\alpha$-thalassaemia probably exists in the negro and Schwartz and Atwater (1972) have described two negro families with mild $\mathrm{Hb} \mathrm{H}$ disease.

The importance of finding populations with appreciable amounts of thalassaemia and $\beta$ - and $\delta$ chain variants to provide data about linkage at these loci has been emphasized by Weatherall et al (1971). Together with Ghana, Liberia offers such opportunities and Yekepa with all these variants concentrated in a small area appears to be a good location for detailed studies.

Thus Liberia appears to be unique in possessing the highest reported incidence of $\beta$-thalassaemia in a purely negro population. The following extract from Sir Harry Johnston's book on Liberia (1906) is as appropriate to the field of haemoglobin studies as to the flora and fauna to which it refers. 'Liberiait is a peculiar country almost rising to the dignity of a distinct sub-district of the West African subregion.'

I wish to thank the Management of the Lamco J.V. Operating Company and Dr Ragnhild Lilljekvist, at that time Chief Medical Officer of the Company for permission to publish these findings. I am also grateful to Drs Kingsbury and Wallace of the Ganta Mission Hospital for their help with the specimens from that district, and also Phinomena Brown, James Suah, and Franklin Bono of the Medical Department, Lamco Yekepa, for their assistance. I particularly wish to thank Professor D. J. Weatherall of the Department of Haematology, University of Liverpool, for his help and advice.

\section{REFERENCES}

Ager, J. A. M. and Lehmann, H. (1958). Observations on some 'fast' haemoglobins: $\mathrm{K}, \mathrm{J}, \mathrm{N}$, and 'Bart's'. British Medical fournal, 1, 929-931.

Allison, A. C. (1957). Population genetics of abnormal human haemoglobins. In Proceedings of the First International Congress of Human Genetics, pp. 430-434. S. Karger, New York.

Arends, T. (1967). High concentrations of haemoglobin $A_{2}$ in malaria patients. Nature, 215, 1517-1518.

Cook, A. and Raper, A. B. (1971). The solubility test for Hb S: a cheap and rapid method. Medical Laboratory Technology, 28, 373-376.

Dacie, J. V. and Lewis, S. M. (1968). Practical Haematology, 4th edition. J. and A. Churchill, London.

Eng, L.-I. L., Lopez, C. G., and Lopes, M. (1971). Haemoglobin $\mathrm{A}_{2}$ in malaria patients. Transactions of the Royal Society for Tropical Medicine and Hygiene, 65, 480-483.

Esan, G. J. F. (1970). The thalassaemia syndromes in Nigeria. British fournal of Haematology, 19, 47-56.

Greenberg, J. H. (1955.) Studies in African Linguistic Classification. Compass Publishing, New Haven.
Heller, P., Yakulis, V. J., Epstein, R. B., and Friedland, S. (1963). Variation in the amount of hemoglobin $S$ in a patient with sickle cell trait and megaloblastic anemia. Blood, 21, 479-483.

Hendrickse, R. G. (1965). Fast haemoglobins in Nigerian infants. In Abnormal Haemoglobins in Africa, ed. by J. H. P. Jonix, pp. 249256. Blackwell Scientific, Oxford.

Johnston, H. H. (1906). History of Liberia. Hutchinson, London. Lehmann, H. and Huntsman, R. G. (1966). Man's Haemoglobins. North-Holland, Amsterdam.

Levere, R. D., Lichtman, H. C., and Levine, J. (1964). Effect of iron-deficiency anaemia on the metabolism of the heterogenic haemoglobins in sickle cell trait. Nature, 202, 499-501.

Livingstone, F. B. (1958). The distribution of the sickle cell gene in Liberia. American fournal of Human Genetics, 10, 33-41.

Livingstone, F. B. (1960). The wave of advance of an advantageous gene: the sickle cell gene in Liberia. Human Biology, 32, 197-202.

Neel, J. V., Robinson, A. R., Zuelzer, W. W., Livingstone, F. B., and Sutton, H. E. (1961). The frequency of elevations in the $A_{2}$ and fetal hemoglobin fractions in the natives of Liberia and adjacent regions, with data on haptoglobin and transferrin types. American Fournal of Human Genetics, 13, 262-278.

Nierhaus, K. and Betke, K. (1968). Eine vereinfachte Modification der sauren Elution für die cytologische Darstellung von fetalem Hämoglobin. Klinische Wochenschrift, 46, 47.

Olesen, E. B., Olesen, K., Livingstone, F. B., Cohen, F., Zuelzer, W. W., Robinson, A. R., and Neel, J. V. (1959). Thalassaemia in Liberia. British Medical fournal, 1, 1385-1387.

Oudart, J.-L., Diadhiou, F., Sarrat, H., and Satagé, P. (1968). L'hémoglobine du nouveau-né africain: résultats d'une enquête au Sénégal. Annales de Pédiatrie, 15, 773-781.

Pembrey, M. E., McWade, P., and Weatherall, D. J. (1972). Reliable routine estimation of small amounts of foetal haemoglobin by alkali denaturation. Fournal of Clinical Pathology, 25, 738-740.

Ringelhann, B., Dodu, S. R. A., Konotey-Ahulu, F. I. D., and Lehmann, H. (1968). A survey for haemoglobin variants, thalassaemia and glucose-6-phosphate dehydrogenase deficiency in northern Ghana. Ghana Medical fournal, 7, 120-124.

Robinson, A. R., Zuelzer, W. W., Neel, J. V., Livingstone, F. B., and Miller, M. J. (1956). Two 'fast' hemoglobin components in Liberian blood samples. Blood, 11, 902-906.

Rucknagel, D. L. and Neel, J. V. (1961). The hemoglobinopathies. In Progress in Medical Genetics, vol. 1, ed. by A. G. Steinberg, pp. 158-260. Grune and Stratton, New York.

Schwartz, E. and Atwater, J. (1972). $\alpha$-Thalassemia in the American negro. Fournal of Clinical Investigation, 51, 412-418.

Wasi, P., Disthasongchan, P., and Na-Nakorn, S. (1968). The effect of iron deficiency on the levels of hemoglobins $A_{2}$ and $E$. fournal of Laboratory and Clinical Medicine, 71, 85-91.

Watson-Williams, E. J. (1965). Hereditary persistence of foetal haemoglobin and $\beta$-thalassaemia in Nigerians. In Abnormal Haemoglobins in Africa, ed. by J. H. P. Jonxis, pp. 233-248. Blackwell Scientific, Oxford.

Weatherall, D. J. (1963). Abnormal haemoglobins in the neonatal period and their relationship to thalassaemia. British fournal of Haematology, 9, 265-277.

Weatherall, D. J. and Clegg, J. B. (1972). The Thalassaemia Syndromes, 2nd edition. Blackwell Scientific, Oxford.

Weatherall, D. J., Gilles, H. M., Clegg, J. B., Blankson, J. A., Mustafa, D., Boi-Doku, F. S., and Chaudhury, D. S. (1971) Preliminary surveys for the prevalence of the thalassaemia genes in some African populations. Annals of Tropical Medicine and Parasitology, 65, 253-265.

Willcox, M. C. (1973). An assessment of a whole blood solubility test for haemoglobin $\mathrm{S}$ in a West African population. Medical Laboratory Technology, 30, 205-210.

Willcox, M. C., Weatherall, D. J., and Clegg, J. B. (1975). Homozygous $\beta$ thalassaemia in Liberia. Fournal of Medical Genetics, 12. (In press.)

Zetterström, K. (1969). Ethnographic Survey of south eastern Liberia. Preliminary Report on the Kru. Tubman Center of African Culture, Robertsport, Liberia. 